\title{
From regional society to migrant society: a study on urban transformation in China
}

\author{
Daming Zhou
}

Received: 10 May 2020 /Accepted: 5 August 2020 / Published online: 08 September 2020 (C) The Author(s). 2020 Open Access This article is licensed under a Creative Commons Attribution 4.0 International License, which permits use, sharing, adaptation, distribution and reproduction in any medium or format, as long as you give appropriate credit to the original author(s) and the source, provide a link to the Creative Commons licence, and indicate if changes were made. The images or other third party material in this article are included in the article's Creative Commons licence, unless indicated otherwise in a credit line to the material. If material is not included in the article's Creative Commons licence and your intended use is not permitted by statutory regulation or exceeds the permitted use, you will need to obtain permission directly from the copyright holder. To view a copy of this licence, visit http://creativecommons.org/licenses/by/4.0/.

\begin{abstract}
This paper considers the process of the change in Chinese society-in which its people went from being regional to being migrant in urban communities-and recognizes urban transformation as being based on and an expression of cultural transformation. The transformation of urban communities accompanied the "migration era," and China's urban communities, in fact, have been gradually changing from a relatively closed regional society to a diverse and civilized migrant one. The diversification of migrants has caused many problems for cities during their transition, affecting such aspects of social life as the equal enjoyment of public resources, the changes in family and kinship, regional discrimination, the complexity of interpersonal and ethnic relations, etc. The related topics are worthy of further discussion.
\end{abstract}

Keywords Regional society $\cdot$ Migration $\cdot$ Urban community $\cdot$ Cultural transformation

\section{Introduction: conceptual analysis and methodology}

In past discussions of "cultural transformation" some scholars, such as Lin Shurong, believe that "social transformation" and "cultural transformation" are two

Zhou Daming (周大鸣) (1958-), professor of anthropology and director of the Center for Research on Migration and Ethnic Groups at Sun Yat-sen University.

D. Zhou $(\bowtie)$

Center for Research on Migration and Ethnic Groups at Sun Yat-sen University, Guangzhou, Guangdong Province, People's Republic of China

e-mail: hsszdm@mail.sysu.edu.cn 
limited concepts. ${ }^{1}$ In contrast with cultural transformation, Lin uses "cultural change," believing that there is no so-called cultural transformation-namely the complete change of a culture from one model to another, with the second completely different from the culture of the past. Such a scenario is unlikely. Instead there would be continuations, breaks, revivals, and innovations in a given culture as it changes. Other scholars have agreed to the use of "cultural transformation." For example, Zhao Xudong believes that, in the case of China, with the change of the mode of dominant power, a fundamental change of cultural form was taking place; meanwhile, the use of the concept of cultural transformation in contemporary society was also a strategic choice (Xinjian et al. 2012, 182-202). The point of view taken in this article is that "cultural change" and "cultural transformation" are two different expressions of the same phenomenon and are of no conceptual difference. Both are aimed at thinking about changes of social and cultural phenomena. In this paper, the author prefers to use the concept of "cultural transformation" to analyze the sharp changes in the structure of contemporary urban communities in China.

The author's previous work on cultural transformation in the process of urbanization as seen from the perspectives of family, social relations, and social integration, indicated that cultural transformation was specifically reflected in the weakening of ethics, changes in social "circles," rural integration models, and the utilitarian orientation of interpersonal relations (Daming 2013). Chinese culture of the past was formed on the basis of agricultural civilization, while modern urban China has surpassed the rural, with China changing from an agricultural society to an urban society. Has this been accompanied by cultural transformation? At the same time, have our cities undergone transformation? Yang Qingkun pointed out that great change had taken place in Chinese cities since modern times. He regarded urbanization in the period from the mid-nineteenth century to the midtwentieth century as the process of treaty port urbanization. From the foundation of People's Republic of China to the end of the twentieth century, China's urbanization process experienced three stages: high-speed urbanization, counter urbanization, and moderate urbanization; correspondingly, the urban organization system also experienced changes, and faced challenges and problems such as organizational utility and efficiency (Chuangchu and Qingkun 2001). The argument of this paper is that cities in contemporary China are in a period of transformation. In other words, Chinese cities in the past were regional cities built on a regional society; they are now in transition to becoming migrant cities.

This article is based on the author's fieldwork on traditional Chinese society and migration. In the 1990s, the author conducted an in-depth investigation in Fenghuang Village, a traditional village in South China, reconstructing nearly one hundred years of changes o by means of observing perspectives of cultural transformation and explaining the trend of rural urbanization. Similar research focused on the Lingnan area and later expanded to Hunan, Sichuan, Shanxi and other places. In the 1980s, China's reform and opening up drove the transfer of the rural labor force to cities. The author conducted comprehensive studies on various

\footnotetext{
${ }^{1}$ Speech at the 11th Anthropology Advanced Forum which is held on October, 14th 2012.
} 
groups of "rural-urban migrant workers" (including nannies, casual workers, and construction workers). In the last decade, the author has focused on new urban migrants, put forward relevant theoretical paradigms for the study of new urban migrants, called on academics to attach importance to the study of new urban migrants, and published a book titled New Migrants in Urban China (Daming 2014a, 2014b). In addition, the author also studied ethnic minority groups in cities and paid attention to their living conditions. The author edited a book titled Ethnic Minorities in the Process of Urbanization in China (Daming 2005), which attracted the attention of the National Ethnic Affairs Commission and they held a special conference on urban ethnic work in China. In recent years, the author has conducted special studies on international immigration by Koreans, Africans ${ }^{2}$, Japanese and other immigrant groups, in Guangzhou, studying the cultural segmentation and cultural integration of Korean communities in Guangzhou, and the social networks and trade of Africans in Guangzhou, etc. This paper is based on past research and demographic data. Of course, many points of view herein are tentative conclusions, and are not definitive, and many issues are still worth exploring in depth. A number of ethnological and anthropological studies are still being conducted on remote rural societies rather than cities, and research on families and communities in urban areas is relatively weak. The author believes that the application of the unique research perspectives, keen cultural insight, and basic methods of anthropology applied to urban research would have some inspiration for urban research and the perspective and method of anthropological theory, and could also promote the transformation of the models of urban governance to a certain extent.

\section{Formation and characteristics of "regional society"}

\section{Formation of "regional society"}

This article attempts to use the concept of "regional society" to describe and summarize Chinese traditional society, with the viewpoint that regional society is formed on the basis of certain regional culture. The author believes that the formation of regional society is related to the following factors: the socioeconomic operating model, the associated national administrative system, the occurrence and shaping of the market system, and the relatively conservative approach to immigration policies. Specifically, traditional Chinese society was based on agriculture, and people living on the land were reluctant to move; over time, they formed the habit of being attached to the land and unwilling to move. The Chinese agricultural tradition is different from those of European and American societies. Xu Zhuoyun pointed out that since the Han dynasty, Chinese traditional agriculture was one of intensive cultivation under which formed a social and economic pattern of smallscale peasant economy. Since the Qin and Han dynasties, the government

\footnotetext{
${ }^{2}$ In fact, Africa is not entirety monolith. Africa includes many countries and language systems, including languages retained as official from the colonial period, namely, French and English. In addition, there are various ethnic groups and tribes that use different languages.
} 
implemented a policy of "emphasizing agriculture while restraining commerce," which was also closely related to the formation of such a social and economic pattern. Restraining industry and commerce did not hinder people's pursuit of land wealth. Although the original intention of the central government's policy was to strengthen the country with agriculture and encourage people to attach importance to agricultural production, it inevitably led to the rise of a small-scale peasant class, typically represented by the stem family as the basic production and consumption unit (Zhuoyun 2012, 8-12). In China's agricultural society, since the family is the production and consumption unit, its main feature is that the purpose of production is for its own consumption rather than commodity exchange. With the continuous growth of the population, the consumption of the peasants likewise grew; however the cultivable land did not increase, and so the only way to obtain more output was to increase labor input in each unit's limited area. This is the phenomenon of agricultural economy involution described by Zongzhi 1986, 65.

In the past, Chinese traditional agricultural society connected these small-scale peasants on a household basis through the local market. A very important feature of the traditional Chinese small-scale peasant economic farming method was shown in the great differences in demand for labor during busy and slack seasons in farming. During farming's busy season, everyone would conduct intensive cultivation the kind of concentration of labor required of embroidery work. During the slack season, peasants could do other business. Therefore, the small-scale peasant economy in the past was diversified, that is to say, in addition to agriculture, a family could also engage in non-agricultural production, such as small handicrafts. Thus, household handicraft was also a characteristic of China's small-scale peasant economy. In addition, as these products of household handicraft satisfied household consumption, they were also exchanged in the local market. In rural areas, the practice of country market-fairs was very developed, with a small-scale market held every 3 days and a large-scale one held every 5 days. Each household would exchange their surplus agricultural products and handicraft products for what they needed and could not produce by themselves. This is also one of the characteristics of traditional Chinese society. Over time, these market towns became trading centers and proto-cities. As far as the development of the market system was concerned, after peasants were embedded in market relations, coupled with the need for cash to pay taxes and others debts, they would rely more on market exchange, eventually, selling land in exchange for money. Peasants became tenant peasants after selling their lands. The government would perform regulate and control such activities through policies adopted after the population of peasants increased beyond the land capacity; however, traditional Chinese population policies were relatively conservative and static. On the one hand, the free migration of population was restricted: since the Qin dynasty, free migration had been prohibited (Zhuoyun 2012 , 26). On the other hand, most of the migration policies launched by the government, such as tunmin (屯民), one of the policies related to permanent migrants in frontier areas, were undertaken for the military purpose of consolidating the northern border defense (Zhuoyun 2012, 33). In addition, after 1949, a very important institutional reform established a strict household registration management system. This strict household registration system restricted the flow of population and their 
migration. Under this registration system, it was not up to an individual to decide where to go. It served, therefore, to restrict population movement between urban and rural areas and between cities, and strengthened the development of regional cities.

\section{Characteristics of "regional society"}

An urban community is a micro perspective from which to observe the transformation of Chinese society from regional society to migrant society. When discussing Chinese cities, Max Weber said that Chinese cities were places where kings, administrators, craftsmen and businessmen settled. They were often political centers and military fortresses. (Weber 1999, 59) The first step in the construction of a political or military fortress is to build city walls with good defense functions. Different from Chinese cities, many European cities are based on religion, the most important and core buildings are mostly related to religious beliefs. Therefore, European cities were sacred centers before becoming secular centers. Yang Qingkun defined urban communities as "non-agricultural and heterogeneous communities," and divided cities into two categories: "military and political cities" and "economic cities," being of the opinion that China initially had only military and political cities, and that only then did economic and religious cities gradually form (Chuangchu and Qingkun 2001:104). Based on the definition of urban communities, Yang Qingkun believed that China's four famous towns were all economic cities: Zhuxian (printmaking) in Henan Province, Hankou in Hubei Province (commercial center), Foshan in Guangdong Province (handicraft industry) and Jingdezhen (porcelain) in Jiangxi Province (Chuangchu and Qingkun 2001). However, many of these cities mainly produced supplies for officials, and such supplies were rarely launched to the market for trading. For example, Jingdezhen was the site of a famous official kiln. Thus, it was difficult to form the foundation for the development of capitalist cities, and the formation and development of economic cities in China were still essentially different from their Western counterparts.

This article proposes that traditional Chinese cities were built out of regional society and here summarizes some characteristics of a regional city formed from regional society: First, residents are mainly from surrounding rural areas. For example, Shanghai is a migrant city. Migrants mainly come from southern Jiangsu and northern Zhejiang. Because of this, the Shanghai dialect is based on the Suzhou dialect, with some changes in tone. There is a saying that "I would rather listen to a quarrel between Suzhou people than a conversation between Ningbo people." The dialect in Suzhou, a city in Jiangsu Province near Shanghai, is gentle and soft; whereas the dialect in Ningbo, a city near Shanghai in the northeast of Zhejiang Province, uses initial tones that are short and intense, like a quarrel. Second, historically, people moved into cities from surrounding areas, so a certain dialect group was taken as the main linguistic body of the city and a regional city was basically based on a certain dialect. For example, though this feature is not particularly obvious now in Nanning, in the past, Nanning had a vernacular dialect that was a branch of Cantonese. The vernacular was spoken in the city, but would have differed outside the city. Another example is that Cantonese is popular in the whole city of Guangzhou; Shanghai dialect is popular in Shanghai; Wuhan dialect is 
popular in Wuhan; Changsha dialect is popular in Changsha. These cities' linguistic groups are mainly based on a common dialect. Third, regional cities are also centers of administrative divisions. Almost every city in China is the center of a region. Of course, this is also related to our history, because China has always regarded cities as military or political control centers. Therefore, the Chinese revolution took the road of encircling the cities from rural areas. There are also regional cities in any given region, which has something to do with the traditional use of cities as the main political control centers in China.

On the whole, although China is a unified country, in fact, the internal differences of Chinese society are great. We habitually divide cultures into different types by regions, such as Central Plains Culture, Southern Fujian Culture, Southern Yangzi Culture, Wuxiang Culture, and Fujian and Guangdong Culture. In other words, there are many types of regional cultures. Nowadays, historical and social science circles have paid more attention to the study of regional society within the framework of Chinese society since the Ming and Qing dynasties. The relations between local regions and the state are often discussed to further study the history of various regions that have been submerged in a larger historical background. In fact, some regional histories might not be synchronized with the general history, and might not have the same development history. As an example, Kunming was part of the Nanzhao Kingdom during the Tang and part of the Dali Kingdom during the Song; in both cases it was relatively independent of the central government.

In like manner, the author's research revealed that Shanxi did not belong to the Song dynasty but rather to the Liao Kingdom during the Song dynasty. Today, Shanxi is referred to as the Central Plains region, but at that time Shanxi was in fact a region of the Liao Kingdom. During recent years' study of regional society we have found that each region experienced its own developmental process and that there are huge differences between regions in China. Concretely, there are regional differences in language, customs, food, and accommodation. Another important point is that the discrimination among Chinese people caused by regional differences is very serious. For example, southerners stereotype northerners, calling the latter "big stupid guys," while northerners also stereotype southerners, calling them "astute little men." Besides discrimination between the north and the south, Chinese discriminate between different places and regions within the same province. If people of different groups have different understandings, there might be an exclusiveness that has a profound impact. For example, enterprises in Shenzhen, Dongguan and other regions that need to recruit workers, only recruit people depending on their regional origin. This situation is very serious. Hence the overall structure of regional society is relatively stable; due to the influences of factors such as ethnic groups, natural geographical environment, history, and especially historical process of migration, there are great cultural differences.

\section{Migration and the transformation of urban communities}

The transformation of urban communities has accompanied the "migration era." Migration is the internal driving force of urban transformation. The large size and 
growth rate of the migrant population and its wide geographical distribution have profoundly changed the population structure of today's society. With the progress of industrialization and urbanization, the number of domestic migrants has been very large in recent years. At the end of 2019, the total population of the Chinese mainland was 1.4 billion, of which 236 million were migrants, indicating that one out of every six people belonged to the migrant population. ${ }^{3}$ In 2019 , the permanent population of Beijing was 21.53 million, including 7.456 million permanent migrants, accounting for $34.6 \%$ of the city's permanent population. ${ }^{4}$

In Guangdong, especially in the Pearl River Delta region, the proportion of migrants is greater. For example, in 2018, Shenzhen's permanent population was 13.02 million, of which 8.47 million were nonregistered residents, accounting for $65 \%$ of the permanent population. ${ }^{5}$ The temporary population of migrants in Dongguan is 6.08 million, and the permanent population is 8.39 million, indicating a prominent proportion of migrants surpassing that of the local residents. ${ }^{6}$ In general, the number of migrants in the Pearl River Delta region has exceeded the original local population and changed the original population structure. In addition, the population movement in contemporary China is generally unidirectional, commonly known as "the spring river flows east." In other words, the population mainly flows from the west to the east, to the southeast coast, and to the larger cities. Based on the comparison of regional population movement data in China in 2000 and 2010, the overall regional changes in the migrant population are as follows: there was an absolute majority of the migrant population in the east in 2000 , and the growth rate of the migrant population in the west in 2010 exceeded that of the east. In 2010, the growth rate of the migrant population in the west was $86.8 \%$, and that in the east was $85.4 \%$. The proportion of migrants in China as a whole is increasing, and the proportions of migrants in various regions are also increasing. However, the proportion of migrants in the east is the largest. Only the proportion in the northeast is relatively small, mainly because there are few economic opportunities and many laid-off workers in the northeast, and it is not easy for outsiders to make a living. The migrant population is still concentrated in the east, though it is also spreading to the central and western regions. In 2015, the migrant proportions of the population in the central and eastern regions were roughly similar, about 20\% (Chengrong 2019). Therefore, the flow of population of the entire Chinese society is not region wide, but nationwide.

\footnotetext{
${ }^{3}$ Source: National Bureau of Statistics, URL: http://www.stats.gov.cn/tjsj/zxfb/202002/ t20200228_1728913.html.Migrant population refers to the population separating from their place of household registration subtracted from the total within the municipal jurisdiction.

${ }^{4}$ Source: National Economy and Social Development Statistical Bulletin of Beijing in 2019 (《北京市 2019年国民经济与社会发展统计公报》), URL： http://tjj.beijing.gov.cn/tjsj/tjgb/ndgb/202003/t202003 02_1673342.html

${ }^{5}$ Source: National Economy and Social Development Statistical Bulletin of Shenzhen in 2018 (《深圳市 2018年国民经济与社会发展统计公报》), URL： http://tjj.sz.gov.cn/zwgk/zfxxgkml/tjjj/tjgb/201904/ t20190419_16908575.htm

${ }^{6}$ Source: National Economy and Social Development Statistical Bulletin of Dongguan in $2018(<<2018$ 年东莞市国民经济与社会发展统计公报 >>), URL: http://tjj.dg.gov.cn/tjzl/tjgb/content/ post_586858.html
} 
The original household registration system was directly linked to many aspects of people's daily lives, such as employment and food and fuel distribution, and so on. In fact, it is not easy to implement household registration reform. Since the enactment of reform and opening up in 1978, without the household registration system being changed, population flow has begun to occur, contributing to rapid urbanization. Around 1978, China's urbanization level was about 18\% (Li 2002), and more than $80 \%$ of population was agricultural. For this reason, China was called a large agricultural country. Since 2011, China's permanent urban population has surpassed its rural population, and it continues to increase year by year. ${ }^{7}$ At the end of 2019, China's resident population was $60 \%$ urban, and its registered population was $44 \% .{ }^{8}$ After the 18th National Congress of the Communist Party of China (CPC), the establishment of a new pattern of urbanization was proposed. It required the transfer of 200 million people to cities, thereby accelerating urbanization.

This large-scale population flow provides residents with more choices. With the increase in the migrant population, China has gradually completed the process of industrialization, urbanization, and modernization, moving from a traditional agricultural society to a modern industrial society. China has entered a period of rapid urbanization and increasingly frequent population flows. Chinese cities have thus entered a period of transformation. As mentioned above, the number of urban migrants account for an increasing share of the total population. The characteristics of the population of Chinese cities, in fact, have gradually embedded the change from a relatively closed regional society to a more open migrant society, as can be observed from the demographic structure.

In contemporary Chinese cities, the proportion of urban population from a single region is getting smaller and smaller. In 1980, the registered population in Guangzhou was 5.01 million. Except for the proportion that is a result of natural growth, most of the current population of 14.9 million is composed of migrants. ${ }^{9}$ China's coastal cities are an example of a migrant society, instead of being regional ones. So why has China entered an era of migrant cities? This is mainly because their population composition is no longer embodied with the flows from purely local rural areas to urban areas. While cities are expanding, the surrounding rural population will join them and the urbanization process will gradually change the surrounding rural areas into urban areas. The rural population will then naturally become urban. In fact, this part of population is not in the mainstream, and is referred to as policy migrants. Policy migrants accounts for only a small proportion of coastal urban migrants. Today, the source and composition of migrants are more diverse. The coastal areas were previously cities with ethnic Han people only. But in big cities like Guangzhou, Shenzhen, Shanghai, and Beijing, individuals from any of China's fifty-five ethnic minority groups is to be found. In a private

\footnotetext{
${ }^{7}$ Refer to the 2011-2014 China Statistical Yearbook (2011-2014<<国家统计年鉴>>).

${ }^{8}$ Source: National Economy and Social Development Statistical Bulletin of the People's Republic of China in 2019 (中华人民共和国2019年国民经济和社会发展统计公报>>), URL: http://www.stats. gov.cn/tjsj/zxfb/202002/t20200228_1728913.html

${ }^{9}$ Source: Guangzhou Statistical Yearbook (《广州统计年鉴》), URL: http://210.72.4.58/portal/queryInfo/ statisticsYearbook/index
} 
conversation with a Yunnan University professor, the author was informed that Yunnan is a province with the most ethnic minorities, with twenty-five different groups found there. The author joked that while there are only twenty five ethnic minorities in Yunnan, there are fifty-five in Guangzhou. Through migration, the source and composition of people are diverse. Researchers from Guizhou University have come to Guangzhou to study the Miao people of southeast Guizhou, because a large number of them have come to Guangzhou to work.

In addition, among the migrant population, diverse characteristics exist. For example, the "ant tribe" group that has emerged in recent years refers to low-income college students living in cities. Because of expansion policy of enrollment for colleges and universities, the number of college students has increased, and employment has become increasingly difficult to find. At present, the starting salary of college students is not increasing but decreasing. College students are considered to be one of the new migrant groups, and the bigger the city, the more such groups there are. In addition, there are new generations of migrant workers and urban white-collar workers who have increased the diversity of the migrant population and the migrant cities. In addition to the domestic population flow, the international population flow is also increasingly frequent. Globalization has caused China to gradually become a target country for international immigrants. By November 2010, there were 593,832 foreign residents in China, most in the eastern coastal areas. South Korea, the United States, and Japan are the top three countries of origin for foreigners in China. ${ }^{10}$ According to the data provided by the Exit-Entry Management Detachment of the Guangzhou Municipal Public Security Bureau, on June 25, 2016, there were 77,000 foreigners living in Guangzhou, with the actual number of people in Guangzhou from African countries was about 11,000, accounting for only $14.8 \%$ of the total foreigners in Guangzhou. Specifically, of those 11,000, there were about 5000 permanent residents and 6000 temporary residents (Kai and Qingju 2016).

Japanese and South Koreans in Guangzhou, who prefer to establish their own commercial and social system, have special shops, supermarkets, and their own restaurants, publications, and churches, which makes things complicated in China. Moreover, the population of such immigrant groups is not shrinking but expanding. Many South Koreans and Japanese who came to the Pearl River Delta region are engaged in professional and technical professions. There are numerous South Korean restaurants and supermarkets in Shunde, Foshan. Shunde is one of the five administrative districts in Foshan City, Guangdong Province, and also one of the largest production centers for air conditioners, refrigerators, water heaters and disinfection cupboards in China; the region is also the largest supplier of rice cookers and microwave ovens in the world. As a result, a large number of South Koreans are actually blue collar, technical workers, and not white-collar workers. Another example is in Yiwu, Zhejiang, and elsewhere, where there are many foreigners who sell small commodities to customers all over the world. Guangxi has many immigrants from Vietnam, Laos, and Myanmar. Many of them came to China in

\footnotetext{
${ }^{10}$ Source: Tabulation on the 2010 Population Census of the People's Republic of China (<<中国2010年 人口普查资料>>), URL: http://www.stats.gov.cn/tjsj/pcsj/rkpc/6rp/indexch.htm
} 
the form of "married brides." These immigrants marry women to form a family. Therefore, this kind of immigration starts from the most basic level. Once a family is established, there will be kinship and a kinship network, which will have a greater impact on the society. After immigrants of different status types enter China, there are many institutional challenges, such as the naturalization of transnational marriage partners, and consideration of whether or not international immigrants can become Chinese citizens, and so on.

\section{Cultural adjustment in urban transformation}

The diversification of migrants and immigrants brought about many problems encountered by the cities during the transition period, and corresponding cultural adjustments need to be made. Beside changes at the policy and institutional levels, there has also been cultural transformation, seen from an anthropological perspective, in the process of urban transformation. First of all, cultural differences are widely variable between regions. With the complexity of the population structure, people bring their own cultures into cities. Therefore, cultural diversity is a very important feature of a migrant society. A phenomenon of transition from regional cultures to diverse cultures in the cities is occurring, initiating many problems in the process of transformation.

Specifically, the first problem is the equal enjoyment of public resources in a way that achieves urban integration. A common problem of today's Chinese cities is that people obtain different benefits though they live in the same city; because of their differing status, such benefits as medical care, education, pension and social security, are not the same. The 18th CPC National Congress proposed a new pattern of urbanization including the residency of peasants. In places like the Pearl River Delta region, the proportion of migrants is very large, and many peasants relocate on a household basis, meaning that their children have to go to local schools in places where they do not have official residency. For this portion of the population, their education and medical security issues are becoming urgent. Now these issues have also aroused great concern in academia. The speed and effectiveness of various reform measures promoted vary at the governmental management level, with land reform being promoted more quickly, and the process of granting peasant residency more slowly. This is related to the current taxation system, whereby China implements central and local taxation systems, namely national and local tax-sharing systems. However, the current state-administered and locallyadministered responsibilities are still not clear. This is partly because in the early days of the central and local taxation systems, China's GDP and fiscal revenue were not large and the issues was considered unimportant. In recent years, the contradiction between the state and the localities in terms of the central and local tax systems is most acutely felt. Generally speaking, under the central and local taxation systems, the state is allocated a little more than $50 \%$, while the province, prefecture, county, and town-level local governments are allocated only a little more than $40 \%$. Education, medical care and city construction are the responsibilities of local authorities, so people working in the Pearl River Delta region are 
obliged to pay social insurance premiums and many other expenses. If they leave the region, they can only take the portion they paid and have no claim to the portion paid on their behalf by enterprises or other entities. This current situation in China reveals that local protectionism is still relatively strong.

Second, similar cultural conflicts are found within the families. In the past, people who lived in the same place believed in the same religion and shared a common culture, sense of identity, and values, making the probability of conflicts between people or families of similar cultural backgrounds relatively small. This can be observed from the divorce rate to a certain extent. In a survey conducted in Fenghuang Village about twenty years ago, the local divorce rate was 0 , revealing that in the traditional rural society, families were extremely stable. But nowadays, the divorce rate is very high in China. An important reason might be the expanded intermarriage circle, with more and more people from different cultures intermarrying. Many people think that marriage is a personal matter. In fact, due to the influence of traditional Chinese family ethics, marriage involves two families. However, people from different cultures have different customs and habits. There may be some specific inconsistencies in the marriage customs, gift giving, banquet arrangement, pregnancy and childbirth customs. The conflicts within cross-cultural families are a likely cause of the rise in the divorce rate. Therefore, in a society undergoing cultural transformation, all units and groups may have to face these problems, from the basic unit family to the larger group.

Thirdly, there may be some cultural maladjustment, in the form of regional discrimination, during the transition period. People frequently have a lot of stereotypes about those from certain places. Research suggests that this situation may occur due to the existence of group identity, namely, self-identification and exclusion. This kind of self-centered psychology is deeply rooted in Chinese people. Another reason is the weakening of traditional moral ethics. In the past, traditional Chinese regional culture was an acquaintance-based society. It was based on three systems: blood, geography, and kinship, which were manifest in the clan system, the geography system, and the kinship system accordingly (Daming 2014a, 2014b). After transition to a migrant society, these traditions were broken, and the basic resources available to people changed. Specifically, the most anti-traditional system is the multi-level marketing (MLM) system, or pyramid-scheme system. Pyramid schemes adopt the method of cheating acquaintances, starting with the most familiar and closest people, first parents and then brothers, classmates and so on. Such a scheme that makes use of the relationship between parents and relatives is against tradition and ethics.

Fourthly, there are more complicated interpersonal relations in the migrant society. In the past, people were divided into "inner and outer circles." In fact, in today's migrant society, we are facing more outsiders, so the question becomes how to establish a trust mechanism and how to build a harmonious society as it becomes more and more complex. Here we propose a concept called "governing the country according to law," while we previously implemented "governing the country by virtue." Governing the country according to law is correct, but if all problems are solved by laws, regulations, and rules, the costs will be very high. For example, practicing law is the most profitable profession in the United States 
because there are so many laws and regulations in that country: there are federal laws, and separate state laws, resulting in a complex, legal system. When a person breaks the law in one state, he may be innocent in another state. Traditional Chinese culture focuses on being an upright person, on "cultivating oneself" and "regulating one's family." 11 The binding force of ethics is higher than that of law. In fact, from a cultural point of view, individual behaviors are subject to social ethics and are not completely handled by law.

Finally, we shall consider the complexity of ethnic relations. The relationship between individuals is becoming more and more complex, and the relationship between groups is still changing in the direction of complexity. In cities, there is the added complexity of the different types of regional people. For example, people from different provinces such as Shandong, Henan, and Hubei are studied in Guangzhou, and there are different dialect groups such as Chaozhou people and Hakka people and in addition to the complexity introduced by different ethnic groups in Guangdong province. Ethnic groups or groups with commonly-held religious beliefs gather together to hold different forms of rituals. In fact, it is the expression of diversified religious beliefs. Another example is that in factories, if there is a conflict between the Han people, generally, the factory can handle it. However, if there is a conflict between people of different ethnic groups, the factory managers will be helpless due to the lack of special management departments and management experience; they can only ask the government to solve the problem. The handling of issues by the government itself might be the cause of these interpersonal conflicts that then become group conflicts. Guangzhou's attitude towards Africans is such a case. With the absence of specialized immigration agencies to perform management functions, Africans can only request assistance from the government when they encounter unfair treatment. The government usually sees such incidents as affecting stability. The current approach is to prohibit residents from renting houses to Africans. Whoever rents out the house will be responsible, the landlord becomes the party that should bear the responsibility, causing the complexity of relationship among the landlords, the government, and Africans immigrants.

\section{Conclusion}

The foregoing retraces the transformation process from regional society to migrant society from the perspective of micro-communities in a city. It can be seen that migration is symbol of urban vitality and a valuable asset to cities. New migrants from all over China have made significant contributions to urban development. The author believes that a multicultural migrant society should not regard domestic migrants as a social problems or require social governance over them; instead, it needs to provide them with better a policy environment and access to public services so that they can enjoy the benefits equal to those of local residents, in order to help them achieve cultural transformation more quickly. The central government has made proposals to "accelerate the reform of the household registration system,

\footnotetext{
${ }^{11}$ Zengzi (曾子), The Great Learning (<<大学〉>)
} 
promote the urbanization of the population transferred from agricultural areas in an orderly manner, and strive to achieve full coverage of basic urban public services for the permanent [migrant] population." The government should continue to improve the systems and measures for the point-based household registration of migrants, the school admission of migrants' children, access to the high school and college entrance examination in different places, and medical treatment in different places. The household registration system should not become a barrier to population mobility. The government needs to increase the ability to provide public services, maintain the fairness of public resources, solve the problem of different treatment in the same city in terms of medical treatment, education, pension, and social security, and let the migrant population share the fruits of reform and development as urban builders. All kinds of social organizations and residents should be extensively mobilized and encouraged to participate in social governance, explore governance models that coordinate people's internal conflicts, promote localizing of public services, and nurture the cultural atmosphere of migrants so as to promote interaction and inclusive coexistence of different migrant groups.

In terms of international immigration, with the deepening of China's participation in globalization, it is necessary to cultivate immigrants' cultures from various aspects such as laws, institutional settings, and social culture. On February 27, 2020, the Ministry of Justice of China issued the Administrative Regulations of the People's Republic of China on the Permanent Residence of Foreigners (Draft for Comment).Some people have raised concerns that some of the provisions in the regulations are set at a low threshold, being not sufficiently detailed and relating only to domestic public welfare; the author asserts that the formulation of these regulations is not only to regulate the administration of permanent resident foreigners in China and to protect their legitimate rights and interests, but also can attract talent, technology and capital to participate in Chinese economic and social construction. The National Immigration Administration, established in 2018, is a specialized immigration management authority in China. There are laws to follow and a governing authority, both of which reflect our country's experience and progress in exploring international migration governance over the years. In addition to management, small, professional, and more comprehensive agencies can be set up to provide services. The author studied the intermediary group of Africans in Guangzhou that built a bridge to enhance China-Africa trade relations, and found that the intermediary group was more stable and had the desire to stay in China for a long time. These families with a stable life in Guangzhou have demands for medical care, children's education, and Chinese learning. Social worker organizations can provide targeted services for them.

China is in a period of transformation and is developing very quickly, but relevant laws and policies are relatively lagging, and there is a lack of related research. Transformation from regional cities to migrant cities demands a compatible cultural transformation with innovation in urban governance concepts and modes. Anthropology, being born of culture, is of great significance for understanding the characteristics of different cultures in migrant cities, dealing with multicultural frictions, and promoting multicultural integration and coexistence. The first book of urban anthropology is about urban ethnicity and about the relationship between urban ethnic groups to which the government pays little attention (Southall 1973). For 
example, discussion on the construction of new urbanization has not yet mentioned the construction of multicultural cities and multiethnic cities. Similarly, when mentioning social development, we do not use the relationship of ethnic groups as an indicator of social development, indicating that many things are still missing. Issues mentioned above, like the weakening of ethics, changes in family and kinship systems, international immigration and transnational marriage are therefore themes that can be discussed in the future.

\author{
Abbreviations \\ P. R. China: People's Republic of China \\ PHD: $\quad$ Doctor of Philosophy
}

Acknowledgements The author thanks the two anonymous reviewers and providers of editorial opinions for their valuable comments.

\title{
Author's contributions
}

The author is the only contributor to this paper. The author read and approved the final manuscript.

\section{Funding}

Not applicable.

\section{Availability of data and materials}

Not applicable.

\section{Ethics approval and consent to participate}

Not applicable.

\section{Consent for publication}

I authorize your journal to publish my papers, if possible. In the meantime, I also accept the opinion about copyright regulation of your journal.

\section{Competing interests}

The author declares that has no competing interests. 


\section{References}

Duan Chengrong (段成荣). 2019. Certain Trends in China's Population Flow (中国人口流动的若干趋势). Beijing Daily (《北京日报》). July 15, 2019, 10th Edition.

Liu Chuangchu (刘创楚), Yang Qingkun (杨庆斿). 2001. Chinese society: From immovability to great change (中国社会: 从不变到巨变). The Chinese University of Hong Kong Press (香港中文大学出版社).

Zhou Daming (周大鸣). Ethnic Minorities in the Process of Urbanization in China (城市化进程中的民族问 题研究). Beijing: The Ethnic Publishing House (民族出版社). 2005.

Zhou Daming (周大鸣). “Cultural transformation in urbanization (都市化中的文化转型)." Journal of Sun Yat-sen University (Social Science Edition) (《中山大学学报(社会科学版)》) 2013 3, 97-102.

Zhou Daming (周大鸣). "The combination of temples and society and the integration of Chinese rural society (庙、社结合与中国乡村社会整合).” Journal of Guizhou University for Nationalities (Philosophy and Social Science Edition) (《贵州民族大学学报(哲学社会科学版)》) 2014a (6), 19-25.

Zhou Daming (周大鸣). New Migrants in Urban China (城市新移民问题及其对策研究). Beijing: Economic Science Press (经济科学出版社). 2014b.

Lian Kai (连楷) and Tan Qingju (谭庆驹). 2016. 100,000 Foreigners Making Money in Guangzhou, most from South Korea, Japan, the United States, India and Russia (10万老外来穗淘金 韩日美印俄籍最 多). Southern Metropolitan Daily (《南方都市报》). September 27, 2016, 1st Edition.

Wu Li (武力). “Research on the process of urbanization in China from 1978 to 2000 (1978-2000年中国城市 化进程研究).” Research on Chinese Economic History (《中国经济史研究》) 2002 (3), 73-82.

Southall, Aidan. 1973. Urban anthropology: Cross-cultural studies of urbanization. London: Oxford University Press.

Weber, Max. 1999. Religion in China: Confucianism and Taoism, translated by Wang Rongfen. Beijing: The Commercial Press (商务印书馆).

Xu Xinjian (徐新建), Xu Jieshun (徐杰舜), Zhao Xudong (赵旭东), Wang Mingke (王明坷), Guan Kai (关 凯), Cai Hua (蔡华), et al. 2012. Social Transformation and Cultural Transformation: A Record of the Cross-Strait Round Table Forum (社会转型与文化转型海峡两岸圆桌论坛实录). Advanced forum on anthropology 2012 (《人类学高级论坛2012卷》).

Xu Zhuoyun (许倬云). 2012. Agriculture in the Han Dynasty: Formation of the Early Chinese Agricultural Economy (汉代农业:早期中国农业经济的形成). Nanjing: Jiangsu People's Publishing House (江苏人 民出版社).

Huang Zongzhi (黄宗智). 1986. Small-scale peasant economy and social changes in North China(华北的小 农经济与社会变迁). Beijing: Zhonghua Book Company (中华书局).

\section{Publisher's Note}

Springer Nature remains neutral with regard to jurisdictional claims in published maps and institutional affiliations. 